\title{
Poverty of Leadership, Coronavirus and Sustainable Development in Nigeria:
}

\author{
By Ephraim Ahamefula Ikegbu ${ }^{1}$, Godwin C. S. Iwuchukwu², \\ Ekanem Samuel Aloysius ${ }^{3}$, Chrisantus Kanayochukwu Ariche ${ }^{4}$
}

\begin{abstract}
:
Historically, Nigeria as a socio-political formation has experienced and still experiencing about 21 years of uninterrupted democratic rule since the civilian takeover of leadership through the ballot box from the military in May 1999. All over the world, civilian or democratic leadership is remarkable for its freedom of expression/speech, rule of law, quality leadership through the provision of infrastructure, health care facilities, quality education and other social amenities. This paper which shall use analytic, expository and rational methods argued that poor leadership, in appropriate policies and pursuit of personal drives have denied the masses the benefit of good leadership and governance. The paper argues further that absence of leadership credentials and rationality have further placed Nigeria on a cross road thereby making it unable to take appropriate steps in combating the novel coronavirus pandemic. Leadership ineptitudeness, political and financial rascality, corruption and high -level ethnic and religious profligacy have denied the people adequate development of education and health sector, which made it difficult for Nigeria to respond positively in the fight against coronavirus. The paper concludes, that consistent and pragmatic elimination/erosion of ethno-religious, linguistic and cultural boundaries from our consciousness will birth into positive mental restructuring of the leadership class that will navigate into a process of positive direction that will make Nigeria to respond positively towards finding solution to problems rather than depending on the west, development of home grown medicine remains a combative therapy in a hopeless situation such as this 2020 global living.
\end{abstract}

Keywords: Poverty, Coronavirus, Leadership, Sustainable, Development.

\section{Introduction:}

Leadership in all matrix and/or categorization implies a sense of direction, instruction, ordering and leading by a person or group of persons to others or groups within a defined geographical divide who may be called followers. For a leader to emerge, it must undergo a recognizable process by those who shall obey and accept instruction given out by their leader. It is this recognizable processes that accord leader the required legitimacy. Leadership whether charismatic, traditional, religious, democratic, despotic, totalitarian and lazier-affaire, a remarkable difference exists between a leader and a follower. The followers expresses quanta of confidence in the ability of a leader to deliver desires. This is why a supposed leader ought to possess special talent or credential in the theatre of leadership. A leader possesses as one of the qualities, the appetite to compromise his interest for the good of his people, this altruistic posture 
which a leader should possess differentiates him/her from the follower. The question that stares us on the face regularly is how frequent does Nigerian leader projects the good of the people before his/her own good? How frequent does the health security of the masses occupy the attention of the Nigerian leader? These two questions above are interconnected and equally directed to one answer.

Nigeria at both military and civilian administration has not experienced a leadership class at all levels that sees the happiness and health status of its nationals as primary. No Nigerian leader past or present has ever seen the investment and development of primary health care as a significant priority to its administration. The simple reason is that the primary health care is for the poor masses. The leaders in all categories and their wards jet out of the country and embrace high breed hospitals with public funds. Medical Tourism and capital flight become part of leadership policies that are geared towards promoting inter and intra colonial malfeasance. Indeed, Nigeria occupies a significant space in the management of world affairs due to its high oil deposit. In the continent of Africa, it plays a major role in determining intra and external affairs in the continent, its rich mineral deposit make it an ever sought bride within and outside the continent. As the most populous black nation in the world, the colour though, has attracted discrimination among the Americans and Europeans, its citizens have nonetheless, contributed to the development of economies of some countries of the world. With the avalanche of contributions, the leadership class has denied Nigerian people global recognition and development due to its poor policy framework in the advancement of health and education sectors of the economy.

Leadership of any organization or state sees creativity, as an indispensable ingredient for quality leadership. Ikegbu (2015: 243) commends in this direction when he attempts to differentiate between coat of many colours by Joseph in the Holy Book and coat of many colours by Dolly Parton a pop singer. In the Holy Book, it symbolized royalty, wealth and affluence, while in the pop singer, it symbolized creativity, intellectual response to scarcity, attempt towards making a proactive response in finding a solution to a confronting situation. This is the aspect of leadership that Nigerian leaders are lacking. The leadership class does not approach situations with the desired quest and appetite for solution save in the regime of Dr. Jonathan Goodluck when Ebola virus was chased out of the country with utmost zeal. Both the presidency and league of ministers were proactive and determined to tackle Ebola virus until it was defeated.

This paper feels that there is something practically wrong with the handling of health situation in Nigeria with regard to the present covid-19 pandemic. The presidency, the health ministry, the Nigerian Centre for Disease Control, the Information Ministry and other related agencies seem to be playing games with the lives of Nigerians. There seems to be a growing conspiracy and connivance with some notable world health agencies to confuse or deceive Nigerians in the handling of this virus basically for personal and/or group economic gains. This egoistic drives that characterized Nigeria's leadership philosophy has made majority of citizens to lose hope in democracy and a system of government which seeks basically to satisfy the good of a select class, and its apologetics while allowing the majority to wallow in abject poverty and frustration. Democracy in Nigeria has further widened the gap between the rich and the poor with utmost determination to sustaining the tempo. This leadership behaviour commonly observe in 
this part of the clime sends a negative signal of rebellion where restructuring and organized revolution could not take place.

This paper is arguing that with the present leadership structure that is geared towards satisfying a class at all levels of governance, executive, legislature and judiciary and with the present shrouded management of the global pandemic where secrecy, dishonesty conversion of funds and palliatives for private use and satisfaction of ethnic region against the other, shows leadership failure. John Locke in one of his works argues that the legislature is prone to be changed by the people if among other things (i) it makes a law that is geared towards protecting itself against the people (ii) it sees itself to be above the law. The above in the wisdom of Locke will lead to a change in government. Using the above Lockean leadership matrix, the Nigerian government due to its avowed ploy to deceive the people using available machinery, it has reached the point of change by way of restructuring and/or amendment that could foster unity between and among members of the state. The paper is arguing that with sincerity of purpose, effective leadership credentials, appropriate policy framework, display of unity in diversity, the Nigerian state will be able to confront its situation such as the coronavirus pandemic in the spirit of Ibuanyidanda. But, if followed with the present exclusive parochial approach, the Nigerian state will be comprehensively trapped in the theatre of utter confusion and derision.

\section{Conceptual clarifications:}

\section{Leadership:}

The concept leadership can be seen to mean the science and/or art of leading, directing, instructing, commanding and positioning a person or group of persons to do or not to do a thing for the purpose of achieving an organizational objectives. The use of science and/or art is intentional. Leadership as a science means that it is methodic, systemic, focused and directed to a particular objective or goal. As an art, it means that it is inclusive of diverse human skills and activities creating and recreating ideas both for the immediate and future use of the people. A common phenomenon in leadership is legitimacy. A leader that intends to issue directives and sees same carried out by subordinates must ensure that he/she has the legitimate authority to do so. One cannot assume the status of a leader if one does not possess legitimacy, or is not recognized by an array of followers who must obey the instructions given by the leader. In this case, for there to be a leader, there must be a follower.

Eyo and Udofia (2016) citing Craig Johnson defines leadership as: "the exercise of influence in a group context... people having the greatest impact on the group or organization. Leaders are change agents engaged in furthering the needs, wants and goals..." (xviii). The position of Craig above may not be significantly different from Mylee Munroe who views leadership to mean "The capacity to influence others through inspiration, motivation by a passion generated by a vision produced by a conviction ignited by a purpose" (54). Both Craig and Munroe acknowledge the power of legitimacy and synergy between the leader and the led in their separate intellectual disquisition. The capacity to influence a group of organization means legitimacy and acceptability status which a leader must enjoy in order to succeed. If a leader is not accepted by the follower, 
it will certainly affect his or her leadership output despite the degree of force as in military leadership. Asouzu views leadership from the point of complementary unity and pursuit of the good and well- being of the generality of the populace. This is what we describe as complementary inclusiveness. It is a type of leadership that seeks to see everyone as a partner in the road to progress. It is a consensual partnership for the development and sustenance of our collective aspiration for the immediate and future living. Leadership of sustainability for all shades of development for all segments of the society.

Plato summed it up by offering an integrative approach to leadership and attempting to extricate leadership from all forms of exclusivity and parochiality that characterized the present circumstance. For Plato, leadership is for all qualified rational personage to aspire disregarding one's social circumstance such as race, sex, colour and class. It is in the spirit of Plato's leadership index of tripodalism and synergistic colouration by involving all persons with peculiar natural consideration that his leadership philosophy is regarded as a masterpiece. Aligning to this form, Ikegbu (2018) argues that: "Humanity cannot proceed with discriminatory practice of excluding a class in leadership roles and expects to make significant progress... leadership is a function of high intellectual and mental deposits which can be found in both genders" (p.197).

Indeed, leadership has about five skills namely - Communication, Awareness, Honesty, Relationship Building, Innovation. These skills are very salient for the survival of every leader. Any leader that cannot communicate his/her ideas effectively to the followers is doomed for failure. Through communication the programmes will be assessed and criticized by the people not for the people purpose of condemning the policies only, but for appraising so as to determine how rich the policies can benefit the people. Other skills are inter connected and are aimed at driving at the expected leadership objectives. There are certain laid down qualities that characterize a leader and these we called leadership credentials. They are as follows: Confidence, Positive attitudes, Inspiration, Creativity, Commitment, Honesty, Intelligence, Focused, Determination, etc. Any leader that is bereft of the above qualities will lose the confidence building mechanism from the followers. In all shades of leadership, these qualities are very primary and salient features that should be deposited in a person before veering into leadership position. Nelson Mandela in espousing the importance of communication in leadership argues that: "It is better to lead from behind and to put others in front when you celebrate victory when nice things occur. You take the frontline when there is danger. Then people will appreciate your leadership" (Excerpt from No. 20 of 30 leadership quotes by Mandela). The Skills and qualities or credentials of leadership if consciously applied by any leader in the business of leadership, they will promote good leadership environment, accelerate growth, ensure proactive cohesion and integration of all segments of the people. This aspect should be transparently sandwiched in the leadership of the Nigerian state.

\section{Poverty}

This would be defined as the state of being extremely poor. It may also imply to be inferior in the area of quality or inadequacy of amount. It is a state of a being not been able to materially attend to his/her daily wants especially in the economic and social 
praxes of existence. To live in abject poverty means to be in an economic state of hopelessness. This state of being may be self- induced or inflicted, it may be caused by other parameters other than the self. Poverty could be a reflection of weak social and economic institution caused by an ill-vision leadership.Poverty contextually in this paper implies the state of mental/intellectual weakness of a person or group of persons to be able to generate policies / programs with the propensity of solving a problem. It is the absence of initiating or formulating people-oriented, result - oriented and result-driven policies in a leadership environment. To give credence to this, Ikegbu (p.2015:243) argues thus:

The ruler-ruled contract has evidently collapsed consequent upon the inability of the ruler to see his leadership position as that of a trust. The bond enshrined in the country's national pledge particularly the expressed wordings to be faithful, loyal and honest... to defend her unity and uphold her honour and glory were mere fury and of no evidential or pragmatic consequence going by the leadership policies and attitudes of the leaders. The leaders' inept practices and act of prodigalism were due to lack of vision, projection of self- interest and clear absence of leadership credentials.

Cerebral/intellectual poverty stimulates economic/material poverty. There could be avalanche of natural mineral deposits within and around a leader, but the mental weakness in the leader will not allow him/her recognize the importance of those mineral/natural deposits within the geography of his/her being. This is the case with the Nigerian leadership class where its cerebral poverty has eclipsed its mental consciousness to only focus on oil without recognizing other natural economic deposits that could turn the state to an economic hub.

\section{Coronavirus}

This is an infectious disease outbreak in the late part of 2019 in the city of Wuhan in the Republic of China. Going by a dictionary definition, Corona biologically means any Crown-like appendage of a plant or animal. It can be defined as Lumious Plasman atmosphere of the sun or other star, extending millions of kilometers into space, most easily seen during a total solar eclipse. This virus which broke out late 2019 in China was an endemic virus for some weeks and months circulating within the Chinese region which resulted in closing up economies, social, cultural and religious activities within the area as a way of containing the spread. With the process of time, the virus became pandemic as it circulated to more than 216 countries of theworld.Medical experts and scientist in trying to reduce the spread and death rate advised to avoid crowded places, maintain social distance, personal regular hygiene, wearing of facemasks etc. While waiting for the emergence of the vaccines.

Indeed, Coronavirus epidemic has introduced a new form of living for the entire world. For about 180 days now, the entire world is on stand still, no religious activities, no educational activities, no celebrations of any kind, no transportation of any kind, in fact, the world is in total lockdown. On this high incident, hundreds of thousands have died,

millions of people infected and many more discharged and reintegrated to their respective families. Corona virus spread by contact with infected person, touching infected areas without washing hands and/ or sanitizing the hands, droplets or mucus, through sneezing coughing and other related contacts. As at this period, the virus is till 
spreading and has no proven scientific therapy as it is at the level of community transmission. Its spread through community transmission has reached its crescendo especially in poor countries or developing countries of the world.

\section{Sustainable development}

This double-edged concept implies no less than the ability of humans to strive to meet their needs in the society without consciously or unconsciously compromising the needs of future generations. It means a conscious attempt at enriching our demands and been determined to promote and secure the demands and needs of future generations. In this case, drives of humanity should not be geared towards immediate satisfaction alone but should contemplate life after now. Sustainable in this case, means ability to sustain for an indefinite period without depleting a resource or damaging environment. Development means growth or advancement in shape and size. According to Shagufta, sustainable development means a "real increase in well-being and standard of life, for the average person that can be maintained over the long-term without degrading the environment or compromising the ability of future generation to meet their own needs"(p.252). On the part of Yakubu on social sustainability as cited by Ikegbu argues that:

Social sustainability involves human rights, labour rights and corporate governance. It is the idea that future generation should have the same or greater access to social resources as the current generation (inter-generational equity) while there should also be equal access to social resource within the current generation (intra generational equity) (EJSD,2017,141-154).

Furthermore, Yakubu maintains that sustainable human development could mean that development that promotes ability or present people without compromising ability of future generation. Yakubu therefore, stressed, on continuous improvement on the social well -being and quality of life (61-72).To buttress the above, Enyimba Maduka (2016:3) writes that: "to sustain the environment and its constituents element is to ensure improved growths and maintenance of man, plant, animal and other forms of life resident on earth or natural environment. Pressing further, he argues that the word sustainability is drawn from the word sustainable which is in turn derived from the word sustain and this means "to give help or strength to". To this, Ikegbu (2017) sums up by adducing that sustainability is the process of giving help or strengthening something, in this case environment in other for it not to be weakened, destroyed, depleted or degraded. (147). It is indeed, the conservation of ecological balance by avoiding depletion of natural resources (136).

From the position above, it means that the environment is central to any talk about sustainable development. Again, conservation, prevention and sustenance of the environment are not predicated upon the good of humanity alone, but all lives in it both at its aquatic, terrestrial, land etc. should be sustained, preserved for now and in the after now. As the global pandemic virus is being attacked, using different therapeutic models, conscious leaders must make efforts not to damage or threaten the other lives in the environment. 


\section{Leadership and coronavirus outbreak:}

As the world grows larger in time and space, it expands in different dimensions and scale. Its expansivity in science and technology, economy and political leadership pose great danger to global friendship, bilateral and multilateral relationships especially in the area of trade and commerce. With rapid improvement in science and technology, industrialization of states takes a greater turn without recourse to its consequences to humanity, environment and other non-human lives. Responsive and responsible leadership takes cognizance of consequential effects on environment and the people before initiating any policy framework with a plan to achieving sustainability. This is premised on the logical strand that the people remained the strength of any leader (Gidi Gidi bu ugwu eze).

It is the primary concern of a leader to think appropriately about the welfare of its citizens in all facet of existence. The provision of infrastructural amenities, health, education and good environment should constitute the primary duties of a leader. Also, the security of its nationals should dominate its leadership policies. On the contrary, a parochially ethnic chauvinist, religious bigot and ill-vision leader does not bother himself/herself about the welfare and health status of the citizens in all segments. It is sad that leaders of African states are mostly politicians and not statesmen. Ikegbu had argued elsewhere that politician seeks to know the next election date and their relevance in such election. However, a statesman considers where his country will be in the global map in centuries to come when he would be no more in existence. This egoistic and selfseeking philosophy remains the driving force militating against leaders in various facets, it is the same attitude that is causing Nigeria fortune in both human and material resources in the wake of global coronavirus pandemic. In the same connection Ariche (2018) maintains that "some of our political leaders cater away with billions of dollars to international banks of Europe and America. The Presidency, the legislatures and judiciary are not free from this practice" (p.39). Corroborating this Amalu and Adetu (2018) holds that "corruption and the absence of good governance have led to unfavourable policies and poor policy implementation" (p.75)

Coronavirus which was endemic later became pandemic as it spread to all continents of the world and to about 216 countries. The virus touched its feet in Nigeria on $27^{\text {th }}$ of February, 2020 through an Italian worker in Lagos Nigeria who traveled from Italy to Lagos Nigeria on this, the Nigeria Centre for Disease Control (NCDC) stated:

The Federal Ministry of Health has confirmed a Coronavirus disease (COVID-19) case in Lagos State, Nigeria. The case which was confirmed on the $27^{\text {th }}$ February, 2020 is the first case to be reported in Nigeria since the beginning of the outbreak in China in January 2020. The case is an Italian Citizen who works in Nigeria and returned from Milan, Italy to Lagos Nigeria on the $25^{\text {th }}$ of February, 2020. He was confirmed by the Virology Laboratory of the Lagos University Teaching Hospital, part of the Laboratory Network of the Nigeria Centre for Disease Control.... https://ncdc.gov.ng

It went further to list steps to follow in order to contain the spread of the virus as follows:

* Regularly and thoroughly wash your hands with soap and water, and use alcohol-based sanitizer 
* Maintain at least $1 \&$ half metres (5feet) distance between yourself and anyone who is coughing or sneezing

* Persons with persistent cough or sneezing should stay at home or keep a social distance, but not mix in crowd.

* Make sure you and people around you follow good respiratory hygiene, meaning cover your mouth and nose with a tissue or into your sleeve at a bent elbow or tissue when you cough or sneeze. Then dispose of the tissue immediately...https:/ncdc.org.ng. According to Linsey as cited by Apoorva Mandavilli "it is refreshing that W.H.O is now acknowledging that airborne transmission may occur..." (New York Times, 9 ${ }^{\text {th }}$ July, 2020). The above and other advisory measures were issued out by the government in concert with the NCDC. Beyond these personal hygiene listed above, other unfriendly policy measures were taken by government such as closing down all schools, worship places, markets, and airports, parks, and transports services, offices both public and private with essential offices rendering skeletal services. The closing up of the above service centers were in line with the practice in other countries of the world where coronavirus played host. To what extent has these measures curtailed and checked the spread of coronavirus? How has the lockdown policy at intra and inter-state levels curtailed the spread of the virus especially community transmission where the Nigerian state is at the moment? The question above are germane because, at the present, Nigeria has about forty three thousand cases of coronavirus across the states with Lagos recording the highest number. About Nineteen Thousand two Hundred of this number have been discharged while about Eight Hundred and Ninety Five deaths recorded(NCDC Global update).

Inspite of the measures taken, an average cerebrally induced Nigerian citizen may doubt the sincerity of the quoted figures, raising issues of suspicion and manipulation of the figures for selfish purposes. This is premised on the fact that Nigerian government and its lieutenants have a long history of corrupt and fraudulent practices,as they could see every situation pleasant or unpleasant as an opportunity to make wealth for themselves, and their impious cronies. The argument of this paper is further strengthened in the outburst of a Benue woman, Mrs. Susan Idoko - Okpe that:

While she only arrived in Nigeria on March 22, the Covid-19 positive result tagged her own, was conducted about February 29... The owner of the Covid-19 positive test was identified as a 62 year old Ms. Susan Okpe, her own name is Mrs Susan Idoko - Okpe and she is 58 years old, she said she has been detained in Abuja National Hospital since late March, she had shown no symptoms of Covid-19 or that of any other illness but she was subjected to Covid-19 treatment against her will.https://healthwise.punchng.com.be.

It took the intervention of the National Assembly of Nigeria to secure her freedom. Similarly, the proprietor of Daar Communication, owners of African Independent Television (AIT), Ray Power, High Chief Raymond Dokpesi and his son were taken into isolation on account of Covid-19. The result of the test conducted on them were not shown to them. For the days spent at the isolation center, they were only given malaria drugs. In a thank you message aired on YouTube, he wondered whether there is a relationship between Malaria and Corona virus and if the Malaria drugs can be used to cure Covid-19. He contends succinctly that every medication administered to him and 
his family members were malaria drugs and wish to know if Covid-19 which is a virus is synonymous with malaria parasite. This was corroborated by the pointblank news.com of 16 ${ }^{\text {th }}$ May, 2020with the caption: Covid-19, we were treated with Malaria medicines. Raymond Dokpesi AIT founder, reveals, "I am confused we were given malaria drugs"... I still have doubt in my mind and I need to be educated. What's the difference between Covid -19 and Malaria? Every drug we were given were malaria medications. He continued, "A number of persons who tested positive were checked in reputable labs, hospitals in Abuja and were found to have malaria parasites in their blood streams. When did malaria become synonymous with Covid-19?” Point Blank News, May 16, 2020.

Government's insincerity and fraudulent dispositions in handling issues of governance may have prompted the governors of Kogi and Cross river states respectively to deny the existence of Covid-19 outbreak in Nigeria and Kogi and Cross River in particular. For the Kogi State governor Yahaya Bello, he had on the 25 $5^{\text {th }}$ March 2020 stated in a video posted on his Facebook page that: "Ninety Percent of the noise about Covid-19 is for political, economic, financial (or) material gain. The other 10\% (relates to) ordinary flu, like the common colds Nigerians generally suffer". On the part of Cross River State, governor, Prof. Ben Ayade, he questioned the rationality of social distancing. According to him:

You don't need social distance when you are properly protected because for your mucal glands that secrets the mucus and the mucins already form a network of coats to attack the virus... mucins a major component of mucus can act as a selective barrier but disease can ensue when much structure and production are abnormal (Ayade, April 9, 2020https://gga.org.covid-19)

It defeats every logical claim as to whether or not there is coronavirus in Nigeria. For this paper, Covid-19 is real, but the leadership structure and its management give every reasonable person to doubt the magnitude and allocation of figures amongst states and the Federal Capital Territory as carriers. Nigeria has a porous health sector and bifurcated statistical structure to the extent that it deals with unrealistic or projected figures especially, when there is some pecuniary interest. Moreso, it yields to cerebral doubt due to the fact that those tested were not given access to the test result which remains the property of the patients. With the embarrassing situation that the world is plunged into, the way out is a formidable responsible and integrity based leadership. A leadership that does not compromise the health and welfare of its nationals. At the time the virus broke out in China, Italy, France, Spain and the United State of America, Nigeria would have shut down the airspace and disallow flight entrance to Nigeria. All the borders would have closed as a proactive measure, but personal interest played out.

Leadership is not for the self, but for the people. A leader ought to be a servant of the people. In the Nigerian case, it is the other way around. Several billions of Naira have been expended since the outbreak of the novel Covid-19 purportedly for building isolation centers, giving palliatives and other claims by the leadership of the country.In the real sense of it, the monies that are converted to private purse are much more than what was spent on the people. The beauty of this Covid-19 in Nigeria is that it has somewhat brought inequality to a halt, before this period, government agents and leaders would have been embarking on medical tourism with their families, using public funds to access good medical care at the expense of the common man and woman. But with 
Covid-19, all the international and local flights were shut, therefore, no allowable reckless movements of any kind, even now the international flights, airspace and other activities are gradually picking up, they are not without strict observance of protocols and health analysis. If Nigeria were to be a country with good leadership, all these monies looted by individuals and government agencies such as EFCC, NDDC, Customs, etc. would have been used to equip the health sectors and education subsector of the economy for optimal use.

\section{Coronavirus and sustainable development:}

The trio of Socrates, Plato and Aristotle in their individual philosophical reflections propagated a leadership model that anchored on morals for the good of the citizens of today of their time without compromising the common good of the citizens of their future. Departing from the Athenian leadership model by Socrates was because of moral enslavement by the leaders and the very fact that those who were in power used it as a means to an end. They compromised the sanctity of moral leadership for the present and also for the future. The stern position of Socrates in effecting change from the Athenian turpitude earned him his death in the uncanny manner.

Plato who was trained under Socrates and whose pupilage under Socrates reasonably positioned him to high moral discipleship of Socrates was angered by leadership rascality of the Athenians and he saw ignorance as the major flaw of the leaders which caused the death of Socrates. In his philosophical epistle contained in his famous book, The Republic, Plato set out for a political reconstruction and re-engineering anchored on the value of education that is intended to banish ignorance from the consciousness of Athenian leaders. Though an idealist, his idealist conscription of reality was aimed at putting a leadership structure with the propensity of serving the people adequately in the present without denying them such opportunity in the future. The essence of leadership and its virtue is the common good of the people of the present and not compromising its sustenance for future existence.

Aristotle writing in the Politics from the realist bent, did not significantly depart from the moral posture of Socrates and Plato, rather he followed the trend and sees the functions of government as that of service for the people. He joined Plato's assumptive trend that government or state is a natural creation in an organicist arrangement, implying that whatever affects a part of the organism will certainly affect the organism as a whole. No unit or part of the organism should be dispensed with. This argument was buttressed by Ikegbu and Akpan (2018) that every segment of the society is important and uniquely destined for a purpose. Ensuring the continuity of the present existence without compromising the future existence propelled the likes of Thomas Hobbes, John Locke and Jean Jacques Rousseau to argue that the state is a creation of man to serve its purposes. They are the apostles of the Machine theory of the state, and for them, the state evolves as a result of a social pact between and among the people.

Take the case of Hobbes in his Leviathan, he posits that excessive display of right by the people in the state of nature was what led to the state of civil society through a social contract. In the state of nature of Hobbes which means a state of crudeness, people were owners of everything. To exert control over natural goods of life by all persons at the 
same time triggered off conflict due to the fact that there was lack of obedience to natural law, which is law of reason. To this, there was war of all against all, collapse of industry, letters, navigation, life became brutish, nasty, poor and short. For society to live for the present and future there is need to transmute from the state of nature to the state of civil society through a social contract. The sovereign upholds the sanctity of individual right with him not part of the contract

Hobbes' assumptive position within the context of this paper favours a dictatorial leadership model. With the above model, management of disease in the event of outbreak such as coronavirus will be at the mercy of the ruler. Policies and programmes to be initiated will be according to the ideals of the ruler. This type of governance will not guarantee sustainable development.

Locke's social philosophy with reference to his state of nature and civil society was humanistic and rosy unlike that of Hobbes who gave sordid description of man as rapacious, bellicose, pugnacious, and cantankerous. For Locke, the state of nature is rosy and peaceful. Locke favoured a government of representation recognizing the people as owners of sovereign power and could use same to remove whoever that is representing them when it is observed that such person is acting contrary to rules of engagement. He accords the people the ability to make wealth reasonably without compromising future wealth nor hindering others. To justify the private reasonable acquisition of wealth, Locke argues: "Although, persons belong to God they own their fruits of their labour. When a person works, that labour enters into the object. Thus the object becomes the property of that person". However, this positions of Locke does not go without a proviso which according to him is that one may only appropriate property in this fashion if there is enough left in common for other goods. This Lockean view above made some political theorists to see him as not an economic leveler due to the fact that his philosophy of private property favours capitalism.

Rousseau in the Social Contract sees man as an innocent creature who became corrupted due to his acquaintance with the society. According to him: "Man is born free but everywhere in chains". This is the opening sentence in the Social Contrast which was written in 1762, but still relevant till today. According to him as captured by Anne Deneys- Tunney:

The discovery of tools and technology and the building of cities and social organizations... gives way to right of the strongest where a reign of inequality destroys man's original state of happiness and freedom. Because of man's perfectibility, the passage from a natural state to a social one is both an accident and necessary(https//:www.theguardian.com).

Rousseau had in mind a perfect state where individual will of the people will give way for the general will. He had the consciousness of creating a state that will be anchored on unity for the present existence without compromising the possibility of the future existence. But this consciousness, the appetite and zeal of instilling this structure of unity became eroded the moment man embraces civil society.

In the present Nigerian leadership and its response to the challenging phenomenon Covid-19, there is nothing clearly showing the readiness of the leadership to promote unity, health security of the nationals at the moment let alone sustaining such programs and policies for future living. It seems that Nigerian leadership is employing cosmetic 
approaches in tackling the Covid-19 pandemic. This is because, the reliance of the government so far as facts on ground seem to suggest, is for any kind of vaccine to be released by the western world. Proactive leadership has gone as far as encouraging their pharmaceutical companies, scientist virologists and other medical scientists to embark on research for possible vaccines for Covid-19. In some countries like Madagascar, a traditional syrup for Covid-19 was brought. Despite its acclaimed therapeutic potency for covid-19 some countries of the world were quite critical of its traditional and prejudicial connotations. But in the case of Nigeria, plethora of strikes in the health and educational sectors are what is gaining currency. It is disheartening that in this challenging period, the country's think tank has been on strike for the past five months. The lecturers of Nigeria federal universities went on strike for plethora of breach of agreements with the government which include revitalization of Universities for optimal service delivery in line with the NEEDS assessment amongst others. Other countries that are facing this Covid-19 phenomenon are gradually opening up their sectors including education which is the engine of development, but educational sector and sustainability paradigm remain a myriad of confusion and instability. For there to be sustainable development in this present situation, the leadership class has to think outside the box and optimally confront the new normal. Sustainable development cannot take place in a dishonest leadership with convoluted and weak institutions, but a sincere, proactive and pragmatic leadership devoid of ethnic chauvinism and religious bigotry can yield to the realization of sustainable development even in the face of Coronavirus pandemic.

\section{Conclusion:}

This paper has argued constructively that inordinate, polarized, ethnocentric, ethno-religious and corrupt leadership as presently observed in all facets of the Nigerian state have not helped in the combat and/or management of Covid-19 pandemic. The paper has raised concern that cerebral poverty has so affected the sensibility of the leadership class which has made it pursue personal economic and material drives at the expense of the teaming population. It is argued that the present leadership due to its weak policy formulation and implementation rather than see to the wellbeing of the nationals, has propagated policies that favoured intra and inter colonial mantra. The future of average Nigerian has been mortgagedon the altar of self-esteem.

It is the conviction of this paper that a pragmatic vision - driven, collective will and cerebral leadership that is people oriented will be able to tackle the problems that confront Nigeria as a nation even in the face of Covid-19 pandemic. It concludes that the present state of selective approaches, guess work and ethno-religious considerations in administering palliatives meant for the vulnerable without selection will create divisiveness and unpopularity. The much chorused sustainable development, vision 2020 and millennium development goal will elude the country Nigeria as it steps up to measure with the rest of the world. For sustainable development to take place, a proactive conscious and transparent leadership attitudes must be as a matter of urgency inculcated into the leadership consciousness to sustain both human and non-human lives for the present without compromising the future. This evangelism and/or sermon of new leadership morality should be all inclusive devoid of ethnocentric, ethnoreligious 
and chauvinistic segmentation of the Nigerian state. Only in the aforesaid arrangement and ordering can we boldly confront the prevailing circumstance of the Nigeria's existence in the present covid-19 and sustainable development.

\section{References}

Amalu, Nneka S. and Adetu, Moyosore O.(2018). "Food Security and Nigeria's Development since Independence: Opportunities and Constraints". International Journal of Public

Administration and management Research (IJPAMR) Vol.4, No.4. Pp.69-81.

Approva Mandaville(2020). "The Coronavirus can be Airborne Indoors, WHO says". New York

Times. 9th July.

Ariche, Chrisantus K.(2018). "Reassessing Corruption in Nigeria from the Perspective of

Aristotle's Virtue Ethics". International Journal of Peace and Conflict Studies (IJPCS) Vol. 5. N0.1pp. 33-46.

Asouzu, I. Innocent (2004). Methods \& Principles of Complementary Reflection in and Beyond

African Philosophy. Calabar: Unical Press.

Asouzu, I. Innocent (2007) Ibuanyidanda: New Complementary Ontology Beyond World Immanetism, Ethnocentric Reduction and Impositions. Zurich: Lit Verlang GMBH \& Co

Asouzu, I. Innocent (2007) Ibuaru: The Heavy Burden of Philosopby Beyond African Philosophy. Zurich: Lit Verlag GMBH \& Co.

Asouzu, I. Innocent (2003) Leadership \& Ambivalence of Human Interest. Calabar: University of Calabar press.

Ayade, Ben. (2020) "when a governor believes it's a hoax and ordinary flu-LGA". https//gga.org.covid-19

Dokpesi, Raymond (2020). "Covid-19 we were treated with Malaria Medicines" Pointblank News.com, 16 th May.

Enyimba, Maduka (2016) "Ethics, Environment and Philosophy: Towards Sustainable Development". A paper Presented at the $1^{\text {st }}$ International Conference of the Faculty of Arts, University of Calabar.

Eyo, Emmanuel B and Christopher A. Udofia (2016) Leadership Philosophy: Insights and Decision Theories. Calabar: Ultimate Index Book Publishers.

Hobbes, Thomas (1961) Levithan. Baltimore:Penguin Books.

https://ncdc.org.ng

Ikegbu, Ephraim A. (2014) "The Synergy of Philosophy Leadership and Good Governance in Nigeria" Essays in Honor of Justice Okoi Ikpi Itam. Ogar C. Ogar (Ed) Calabar: University of Calabar Press 1524

Ikegbu, Ephraim A. (2015) "The Poverty of Leadership and Science of Prodigalism in Nigeria: A Philosophical Inquest”. European Scientific Journal Vol II, No 29, October 243-260

Ikegbu, Ephraim A. (2018) “Traditional African Male Dominance in Leadership, Cologenderism: the Need for Gender Balancing". ACPIL: UK Reading, ICGR, Porto, Portugal. 197-209.

Ikegbu Ephraim A. and Samuel B. Akpan (2018) "Ibuanyidanda as an Inclusive Philosophy for Effective Leadership in Nigeria", Global Journal of Research and Review, 5, (28)

Locke, John. (1963).Two Treatise of Government. Awnsham Churchill

Mohammed, Sani Yakubu (2016) "Assessing the Economic and Social Aspects of Sustainable Development" Kill: Journal of Humanities Vol. 61-72

Plato.(1943).The Republic. Trans. Desmond Lee. Penguin Books

Rousseau, Jean Jacques.(1947). Social Contract. New York: Hafner Publishing Co,

Singh, Y.K. (2017) Teaching Environment Science. New Delhi: AP Publishing Corporations 